ISBN: $1646-8929$

\title{
IET Working Papers Series
}

No. WPS01/2011

\section{From the Lisbon Strategy to EU2020 Illusion or Progress for European Economies?}

IET

Research Centre on Enterprise and Work Innovation Centro de Investigação em Inovação Empresarial e do Trabalho Faculdade de Ciências e Tecnologia Universidade Nova de Lisboa

Monte de Caparica Portugal 


\title{
From the Lisbon Strategy to EU2020 - Illusion or Progress for European Economies? ${ }^{1}$
}

\author{
António Brandão Moniz
}

\begin{abstract}
The majority of papers published in the last decades on European Union policy strongly stress the importance of the so-called Lisbon Strategy approved in the year 2000. The same applies to studies and reports on the shift of the European countries towards modernisation and restructuring policy in recent years. This EU development strategy defines a new direction for the coordination of national policies. But why has it become so important? One of the reasons is the fact that many of the papers are based on the concept of "knowledge society" as the key driver for an increased competitiveness of all political and economic regions of Europe. In this context, the term "knowledge" means the inter-linkage of education (including training, qualification, skills) and innovation (including research, information and communication). The use of the concept represents an important shift in the European strategy: further development would not only be based on investment in material infrastructures, but also more on the immaterial ground.

However, this Lisbon Strategy was criticised by many politicians and opinion-makers in the first years of this century because the European structures were not prepared for such a quick change. At the same time, the focus for investment moved away from the traditional support of industrial sectors (manufacturing, agriculture and fisheries, construction) towards the "new economy" sectors. The vision of a knowledge society remained appealing also in a changing international context: the Middle East wars (Afghanistan, Iraq and Israel-Palestine) and the fast growth of the Chinese economy. However, the shadows of new recessions have strongly questioned the options made by the European Council. New challenges have emerged with the need to redefine collective strategies in terms of European development as set by the Lisbon strategy. "Europe 2020" is one more attempt to define a new strategy. But at present no clear path has been identified. Whether the programme will bring about progress for the European economies, or is again an illusion, is not yet clear. This shows, however, that new paths and common strategies are still needed in Europe.
\end{abstract}

Keywords: European Union, Lisbon Strategy, knowledge society, innovation JEL codes: E61, F55, H5, O38, O47, O52

\footnotetext{
${ }^{1}$ To be published at Krings, Bettina-J. ed. (2011), Brain Drain or Brain Gain? Changes of Work in Knowledge-based Societies, Berlin, Ed. Sigma. The author wants to thanks the comments and suggestions from Bettina Krings and Sylke Wintzer. They are not, however, responsible for the final result.
} 


\section{Background for a new European strategy}

By the end of the 1990s, Europe was facing important economic challenges of global competition. The growth of the gross world product (GWP) was around 3\%. Emerging market economies were accessing the financial markets. The strong economic performance of the United States over nearly two decades was an important factor behind the strengthening global economy. An important long-term driver of the global economic expansion in that period, and particularly that of the United States, has been the diffusion in depth and breadth of the new information and communication technologies (ICT).

Since the late 1970s, microelectronics has no longer been just a range of devices applied to some industrial machinery inducing automated production processes, but a wide variety of technologies used in all economic activities. Many industrial jobs were lost due to the technological change, but most of the challenges were related to the field of knowledge: competences were changing, new skills were needed in all sectors, ICT was using new types of knowledge, and the labour market was under pressure. Some experts even predicted that:

"in the long run the employment problems of technical change caused especially by the intensive use of microelectronics can be solved only by further substantial reduction in working time" (Friedrichs 1980: p. 59).

Ten years later, in the Clinton-Gore era, increased investments decisively pushed the US to the forefront of economic modernisation.

"Just as the highway system and electrical power grid were the infrastructure for the industrial economy, so our information networks will be the highways for the new economy. Without a state-of-the-art electronic infrastructure throughout organizations, no country can succeed" (Tapscott 1996, p. 15).

In those two decades (the 1980s and 1990s), industrial economies were facing strong changes and completely new challenges: these were no longer related to the recapitalisation of companies or inter-sectoral shifts, but to the enormous impacts resulting from the globalisation of businesses and digitalisation of production processes. Organisational networks also implied increased flexibility and quick response to market needs, and the emergence of value chains at the international and global level (cf. Berting et al. 1980; Friedrichs 1980; Tapscott 1996).

But the international economy was also facing severe changes in all regions of the world. After a period of major growth, Europe was late to invest in digital infrastructures and Japan was also suffering from economic stagnation. However, the Japanese investment on R\&D was still much higher than in Europe or in the US. This means that Europe 
lagged behind the US and Japan in the "world race" for the dominant economic model of development and growth.

In this period, the so-called "new economy" was considered by national governments as a solution to improve market competition, to increase productivity and to stimulate labour market growth. It was also supposed to offer opportunities for investment in productivity in order to increase both overall economic growth and personal well-being. Large investments in new computer and communication technologies have affected both internal processes and external interactions in small and large enterprises. By the end of the 1990s, ICTs were being introduced at decreasing costs, with the prices of computers and communications falling continuously. Internet was providing immediate access to vast arrays of information and knowledge, enabling businessmen, households and workers to make decisions under different conditions as before (cf. Cornfield et al. 2001). Information on prices and sources of supply were reducing the need for intermediaries and improving the choices for buyers. In a few words, the economic conditions for growth were quickly changing with the investments in ICT. The main aim of such investments was to increase productivity 2 measured as the capacity to generate wealth among the population. In this respect, Europe was far behind the US and Japan (see Table 1).

If we look at the main period of this change (the 1980s), we can see that the production of wealth was much higher in Japan (3.3\% of the average annual growth from 1979 until 1990) than in the US (2.0\%) or in Germany (1.9\%).3 If we take into account a larger period (1979-2008) of almost 3 decades, the difference is smaller but shows the same nature of that growth (Japan with $1.9 \%$, the US with $1.8 \%$, and Germany with $1.6 \%$ ).

Even if we do not consider the total population but the gross domestic product (GDP) per person employed, i.e. the productivity of the labour market, the situation does not change too much - except perhaps that it reveals an even higher capacity of the Japanese economy to improve its growth rates (see Table 2).

2 "Returns on technology stocks, as measured by the NASDAQ composite index, were triple the rate of return obtained in broad equity markets in 1998-1999; the rate of return for Internet stocks was more than quadruple the NASDAQ average. Although the prices of many technology stocks fell significantly after March 2000, all these indices remained high at the end of April" (UN 2000).

3 We could also mention the case of Korea or other European countries such as Spain, Italy or Norway, but these countries have a smaller economic scale than those compared here (US, Japan and Germany). 
Table 1: $\quad$ Real GDP per capita (average annual rates of change)

\begin{tabular}{llllll}
\hline Country & $1979-2008$ & $1979-1990$ & $1990-1995$ & $1995-2000$ & $2000-2008$ \\
\hline United States & 1.8 & 2.0 & 1.2 & 2.9 & 1.2 \\
Canada & 1.6 & 1.5 & 0.6 & 3.2 & 1.3 \\
Australia & 1.9 & 1.7 & 1.5 & 3.0 & 1.7 \\
Japan & 1.9 & 3.3 & 1.2 & 0.8 & 1.2 \\
Republic of Korea & 5.3 & 6.5 & 6.7 & 3.5 & 3.9 \\
Singapore & 4.3 & 5.3 & 5.7 & 3.5 & 2.5 \\
Austria & 1.9 & 2.0 & 1.4 & 2.8 & 1.6 \\
Belgium & 1.8 & 2.1 & 1.2 & 2.5 & 1.3 \\
Denmark & 1.7 & 1.8 & 2.0 & 2.4 & 0.9 \\
France & 1.5 & 1.8 & 0.7 & 2.4 & 1.0 \\
Germany & 1.6 & 1.9 & 1.5 & 1.9 & 1.2 \\
Italy & 1.5 & 2.4 & 1.2 & 1.9 & 0.2 \\
Netherlands & 1.9 & 1.6 & 1.6 & 3.4 & 1.5 \\
Norway & 2.4 & 2.3 & 3.2 & 3.1 & 1.6 \\
Spain & 2.1 & 2.4 & 1.2 & 3.5 & 1.4 \\
Sweden & 1.8 & 1.9 & 0.1 & 3.2 & 1.9 \\
United Kingdom & 2.1 & 2.1 & 1.4 & 3.1 & 1.9 \\
\hline
\end{tabular}

Note: Data for Germany for years before 1991 pertain to the former West Germany. Percent changes were calculated using the compound rate method.

Source: $\quad$ Bureau of Labor Statistics 2009

Tables 1 and 2 show that compared to Europe (and here we stress the German data as mentioned above) the US and Japan have had a stronger position in terms of productivity measured as real GDP per capita or per person employed. In the context of an increasing globalisation of economic activity during this period, the challenge therefore was to improve the competitive capacity of the European economy as a whole. Only Scandinavia and UK were able to increase their capacity, even though not at a constant growth rate. For the European Commission it was clear that some joint decisions had to be made.

Emerging political conflicts in 2001 led to a decline in the world economy and to the restructuring of national investment policies: investment in research and development (R\&D) was postponed, and emphasis was again placed on military and security issues. Thus, the aim of the Barcelona summit of March 2002 to increase European investment on science and technology to a total of $3 \%$ of GDP by 2010 became secondary after the events of September 11, 2001. Following the Spring EU Councils held in 2000 and 2001 in Lisbon and Stockholm, the Barcelona Council is the third such meeting to focus on social issues (cf. European Council 2002). While the Lisbon Council set concrete employment targets to be achieved by 2010 and the Stockholm Council complemented this with intermediate targets, the Barcelona Council concentrated largely on reviewing progress and suggesting minor amendments to the European employment strategy. It was established that the European Council agreed 
" [...] that overall spending on $R \& D$ and innovation in the Union should be increased with the aim of approaching 3\% of GDP by 2010. Two-thirds of this new investment should come from the private sector" (European Council 2002, p. 21).

Table 2: $\quad$ Real GDP per person employed (average annual rates of change)

\begin{tabular}{llllll}
\hline Country & $1979-2008$ & $1979-1990$ & $1990-1995$ & $1995-2000$ & $2000-2008$ \\
\hline United States & 1.5 & 1.3 & 1.5 & 2.3 & 1.4 \\
Canada & 1.1 & 0.9 & 1.4 & 2.0 & 0.5 \\
Australia & 1.3 & 0.9 & 1.7 & 2.5 & 0.9 \\
Japan & 1.9 & 2.9 & 0.8 & 1.4 & 1.5 \\
Republic of Korea & 4.2 & 5.0 & 5.2 & 3.6 & 2.9 \\
Singapore & $\mathrm{NA}$ & $\mathrm{NA}$ & 4.4 & 2.7 & 0.9 \\
Austria & 1.7 & 1.9 & 1.8 & 2.0 & 1.0 \\
Belgium & 1.6 & 2.1 & 1.7 & 1.4 & 0.8 \\
Denmark & 1.6 & 1.6 & 2.8 & 1.6 & 0.5 \\
France & 1.5 & 2.0 & 1.3 & 1.4 & 0.9 \\
Germany & 1.4 & 1.5 & 2.2 & 1.2 & 0.8 \\
Italy & 1.1 & 1.8 & 2.0 & 0.9 & -0.3 \\
Netherlands & 0.8 & 0.8 & 0.6 & 1.3 & 0.8 \\
Norway & 1.8 & 2.0 & 3.1 & 1.8 & 0.8 \\
Spain & 1.3 & 2.0 & 1.8 & 1.0 & 0.3 \\
Sweden & 1.9 & 1.4 & 2.9 & 2.5 & 1.7 \\
United Kingdom & 1.8 & 1.7 & 2.5 & 2.2 & 1.5 \\
\hline N & & & & & \\
\hline
\end{tabular}

Note: Data for Germany for years before 1991 pertain to the former West Germany. Percent changes were calculated using the compound rate method.

Source: $\quad$ Bureau of Labor Statistics 2009

However, most critiques of the Lisbon Strategy referred to the shift in development policy to show the fragility of policies directed only towards supporting the information society. They argued that such policies drew investment away from the modernisation of manufacturing infrastructures, which should be considered as anchors of economic development and growth.

The emergence of the new concepts of "digitalised economies" also illustrated the need for a new European policy following the success stories of the US and Japanese economies during the late 1980s and early 1990s. Benchmark examples from several OECD countries (e.g. Korea and Mexico) underpinned these new policies. The primary aim was to face the problem of the high competitiveness of the US and Japanese economies compared to the European one. The EU-9 and later the EU-12 were loosing ground in the context of an increasing growth and integration of global market structures. In other words, Europe was suffering a loss of competitiveness in comparison to the US 
and Japan and was unable to face these economic trends. The huge bureaucratic structures established in Brussels were also unsuitable to point out new directions for a joint policy in response to the challenges of the two major world economies. The political changes in Eastern Europe as of 1989 also required a common response from the member states. During these years (basically until 2000), the European Union was mainly coordinating support measures for infrastructure and regional development and for the economic and social cohesion in the different societies. This included the development of structural funds for regional development, the European Social Fund, national Community Support Frameworks (CSFs), and other joint funds. In the 1980s, the focus was on the Southern European member states, and one decade later there was a shift to the Eastern European countries. However, only ten years after the major changes in the early 1990s, a new concept was developed as a baseline for a new joint European policy - the so-called Lisbon strategy. Ten years later, we can assess and have access to several evaluations of the impact of the new coordination measures (cf. European Commission DG Research 2009 b).

Institutions like the European Investment Bank, the European Central Bank, or especialised measures as the Structural Funds play an important role in the implementation of these measures. However, it seems that Europe is still in a political development process, where coordination policies should not rely only on economic and financial measures. After the introduction of the single currency (which was not accepted by all member states!), the major joint European measures were the enlargement to 27 states and the agreement on a new treaty. This so-called Lisbon Treaty states:

"The Member States shall coordinate their economic policies within the Union. To this end, the Council shall adopt measures, in particular broad guidelines for these policies" (Lisbon Treaty, Article 2D).

It further says: "The Union shall have competence to carry out actions to support, coordinate or supplement the actions of the Member States" (Article 2E), namely on industry, education and culture. The word "knowledge" is mentioned only once, namely in Article 163:

"The Union shall have the objective of strengthening its scientific and technological bases by achieving a European research area in which researchers, scientific knowledge and technology circulate freely, and encouraging it to become more competitive, including in its industry, while promoting all the research activities deemed necessary by virtue of other Chapters of the Treaties".

In March 2000, the "Open Method of Coordination" (OMC) was introduced by the European Council of Lisbon. It was designed to help Member States progress jointly in the reforms they needed to undertake in order to reach the goals defined in that summit. The OMC should fix guidelines and timetables for achieving short, medium and longterm goals. Initially, these coordination methods were only applied to employment and economic policy. But since then it has been establishing quantitative and qualitative indicators and benchmarks as a means of comparing best practices. When the European Council set the $3 \%$ of GDP objective for R\&D investment at the Barcelona summit, the 
Commission suggested that OMC should be applied for this objective as well. This OMC system also defined the need to translate the European guidelines into national and regional policies by setting specific measures and targets, and it established periodic monitoring of the progress achieved. The Member States should develop similar policy processes.

During the 1990s, special summits were held to discuss the application of OMC to research policy. The Austrian Presidency in cooperation with the Directorate General for Research of the European Commission organised a conference on "Improving Research Policies in Europe through the Open Method of Coordination". In the Action Plan "Investing in Research", the European Commission in April 2003 identified 25 actions for which the main competence lies with the Member States and to which the OMC could be applied. The Committee for Scientific and Technical Research (CREST), whose role is to advise the Council and the Commission on research matters, was given the task to oversee its application. Since 2003, CREST has served as a platform to improve policies for investment in research based on the member states' experiences (cf. CREST 2008).

\section{The European coordination policies}

The common market created by the Treaty of Rome in 1958 was intended to eliminate trade barriers between Member States with the aim of "increasing economic prosperity" and contributing to "an ever closer union among the peoples of Europe", as envisaged by the authors of the Treaty. The issues related with the internal market began to surge in the celebrated Commission White Paper of June 1985 and were incorporated in the Treaty by the 1986 Single European Act. However, it has been recognised by several national government leaders that the reform agenda could not be pursued at EU level alone - as was the case with the 1992 single market strategy (which was designed already in the 1980s) - but that it had to involve the Member States.

The White Paper, which was approved in June 1985 by the European Council in Milan, listed about 300 legislative measures to be taken. These were grouped under three main objectives to be achieved by 1992 (European Commission 1985):

- the elimination of physical frontiers, by abolishing checks on goods and persons at internal frontiers;

- the elimination of technical frontiers: breaking down the barriers of national regulations on products and services, by harmonisation or mutual recognition;

- the elimination of tax frontiers: overcoming the obstacles created by differences in indirect taxes, by harmonisation or approximation of VAT rates and excise duty.

Most of the measures were adopted until 1992, but some further steps had to be taken. The Commission regularly submitted reports reviewing the results obtained and launched 
action programmes to complete projects that were still pending (European Commission 1994). In autumn 2000, the European internal market was considered the world's largest market in terms of the purchasing power of its 370 million consumers, with a decisive weight at the world level. Thus, at least in terms of the market dimension, the goal was achieved. The action programmes aimed at increasing intra-Community trade (by about $10 \%$ a year over ten years), increasing productivity and reducing costs (through the abolition of customs formalities, harmonisation or mutual recognition of technical rules, and supposedly lower prices as a result of competition). The growth rates during that decade were between 1.1 and $1.5 \%$, while the income levels of different countries were brought closer together. The height of the internal market was reached with the introduction of the single currency in 2002.

The main objectives by then were to strengthen the coordination and surveillance of the budgetary discipline and to set out economic policy guidelines. The vision was to create a more integrated Europe in political, as well as in economic and social terms, but based on independent states, with own governments and institutions - something which until now has never been achieved in the world's history (cf. Presidency of the European Union 2000a). This was one of the main illusions in the construction of the EU.

By the end of the 1990s, it was clear that once many of the policy areas involved Member State competences, a closer co-operation between the EU and Member States would be necessary, particularly in view of the expected stagnation of economic growth, unlike the situation in the US and Japan .

The Lisbon strategy launched by the European Council in March 2000 was a comprehensive common European strategy for economic and social development to meet the new challenges: globalisation, ageing, and rapid technological change. It is based on the idea that the European social model can only be sustained by renewing the economic basis of this model, i.e. by shifting the focus towards knowledge and innovation. The European Commission document "Growth and jobs - A new start for the Lisbon Strategy" says:

"In advanced economies such as the EU, knowledge, meaning $R \& D$, innovation and education, is a key driver of productivity growth. Knowledge is a critical factor with which Europe can ensure competitiveness in a global world where others compete with cheap labour or primary resources" (European Commission 2005, p. 21).

In this document, "knowledge" is considered as a unique feature for future economic growth strategies, strongly connected with the use of ICT technologies in all sectors and branches. This new economic factor has almost replaced the European investment strategy on infrastructures and sector restructuring. This earlier policy did not attach major importance to $\mathrm{R} \& \mathrm{D}$, education, training, and innovation indicators at national levels (cf. European Commission 2010c).

However, the EU still invests about one-third less in R\&D than the US. If this indicator (the investment on R\&D in relation, for example, to GDP) is one of the main components 
of "knowledge" as an economic and social factor, than it can be concluded that the EU is not sufficiently using the main tools for the development of the knowledge economy as compared to the US. As much as $80 \%$ of this gap is due to underinvestment in research and development from the private sector, notably in ICT.

"The EU is currently spending only $2 \%$ of GDP, barely up from the level at the time of Lisbon's launch. We must achieve faster progress towards the EU target of $3 \%$ of GDP for $R \& D$ expenditure. This requires increased and more effective public expenditure, more favourable framework conditions and powerful incentives for companies to engage in innovation and $R \& D$, as well as more numerous well-trained and motivated researchers" (European Commission 2005, p. 21).

The recent Innovation Union Survey published in 2011 reveals that this situation persists:

"The US is performing better than the EU27 in 10 indicators [...].Overall there is a clear performance lead in favour of the US and this lead is very slowly increasing. The US has increased its lead in New doctorate degrees, International co-publications, Business $R \& D$ expenditure and License and patent revenues" (IUS 2011, p. 17).

This was the leitmotif for restructuring the policy links between the Commission and the Member States, and for launching a different agenda to cope with the competition problems that Europe was already facing in that period.

The European knowledge society should also include an increased investment on education and vocational training - not only research, science and technology investment -, because all these indicators showed a problematic situation of Europe compared to Japan and the US.

\section{The Lisbon strategy and knowledge for growth (from 2000 to 2005)}

As Maria João Rodrigues says, "the education and training systems should be reformed in order to better cope with the challenges of globalisation and the transition to a knowledge economy" (Rodrigues 2005, p. 11). This has been one of the major aims of the Lisbon strategy, and during this last decade. During the first five years after launching the Lisbon agenda,

"[...] this strategy was translated into an agenda of common objectives and concrete measures, using not only the traditional instruments, such as directives and the community programmes but also a new open method of coordination, which had already been tested in the employment policy and which then extended to many other ones: the policies for the information society, research, enterprise, 
innovation, education, social protection and social inclusion” (Rodrigues 2005, p. 4).

However, this trend of investment in education and vocational training coincided with a specific structural problem in Europe: there have been fewer human resources in the field of science, engineering and research than needed. In 2004, a High Level Group on Human Resources for Science and Technology was appointed by the European Commission to assess not only the basics of the Lisbon strategy, but also the Barcelona target to achieve $3 \%$ of GDP allocated to R\&D. The group estimated that an extra half a million researchers (or 1.2 million research-related personnel) would be needed to meet that goal (cf. Gago et al. 2004; European Commission 2010c).

During the last three decades, there has been a trend towards higher educational attainment all over Europe. This indicator can be correlated with the growth of intangible capital. In the last 30 years, European economies have experienced an increase in investment in knowledge production and dissemination, like education, R\&D activities and training. The development in the OECD region in terms of gross expenditure on $\mathrm{R} \& \mathrm{D}$ in relation to GDP is illustrated in Figure 1.

As shown in the next figure, the EU27 data are far below the OECD average, especially when compared to Japan and the US. The situation does not differ significantly after 2000. Only from 2004, the relative gross expenditure on R\&D increases in Europe, but there is an even stronger increase in the US and Japan as well as in the OECD average. The 2001 US crisis (with the military intervention in Iraq and Afghanistan) pushed Europe to reduce investment on R\&D. Both the US and Europe decided to increase financial support for military actions and to invest on security, surveillance and intelligence activities. That was not the case with Japan, which continued to increase its investment capacity in this knowledge sector. 
Figure 1: $\quad$ Total gross domestic expenditure on R\&D (GERD) - Japan, United Stated, OECD, and EU-27 (in \%)

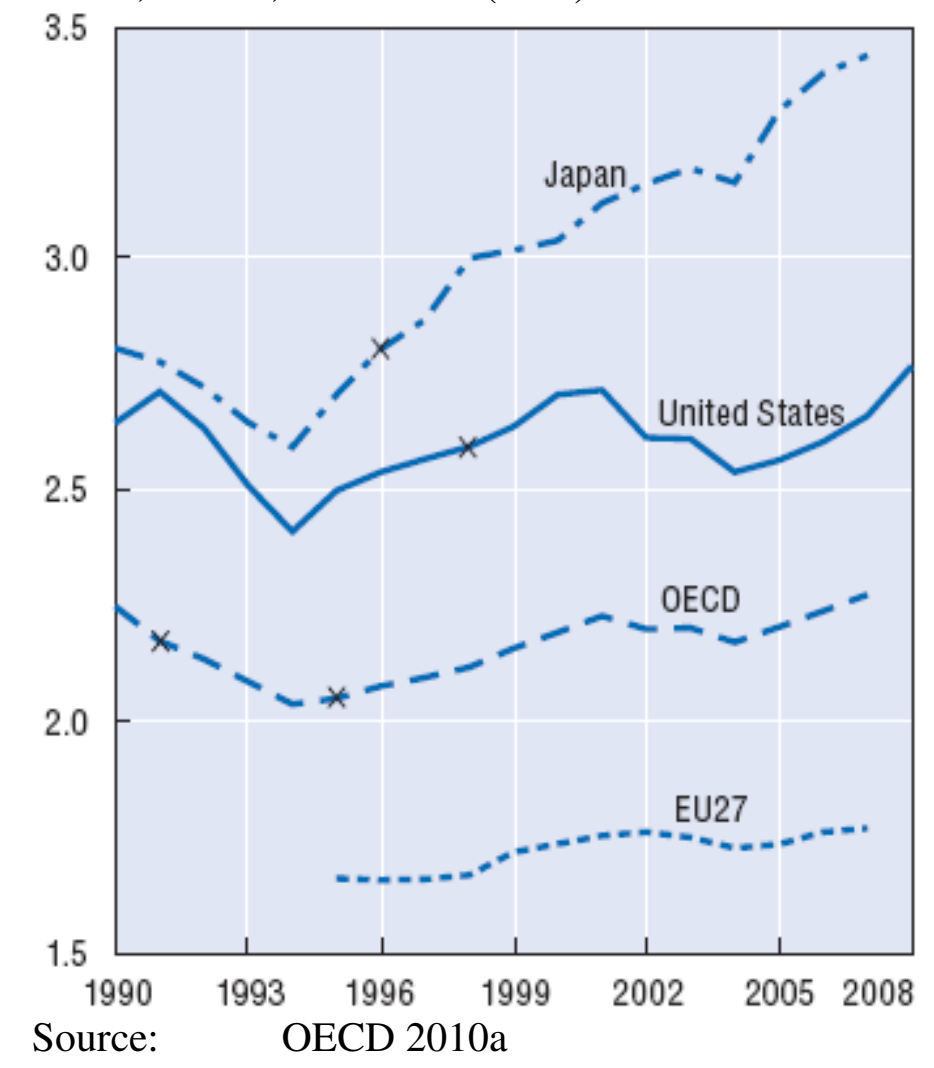

The EU still has the target of investing 3\% of GDP in R\&D and has succeeded in focusing attention on the need for both the public and private sectors to invest in $R \& D$ but with a focus on input rather than impact. It has been declared that there is a clear need to improve the conditions for private R\&D in the EU, and many of the measures proposed in this strategy of achieving 3\% of GDP invested in R\&D activities are intended to support this objective. Some of the measures will give further support to companies, especially SMEs, to get them involved in the R\&D activities (cf. European Parliament 2001).

When looking at R\&D and innovation together, the range of expenditure would be broader and more relevant for business operations and productivity drivers. The European Commission proposes to keep the 3\% target while developing an indicator which would reflect $R \& D$ and innovation intensity.

The 2004 report to the European Commission on human resources in the field of science, engineering and technology states:

"The number of $S \& E$ [Science and Engineering] graduates in Europe is higher than in the US and Japan, but the proportion of people aged 25-64 with a 
university degree is much lower in Europe than in Japan and the US. Europe's strength is in its younger fraction of the population trained in $S \& T$. Europe would be catching up with the US and Japan in terms of researchers by 1.000 workers if employment in $R \& D$ were available for young people, if the numbers of those who choose to study $S \& T$ were not allowed to diminish, if more women were involved in $R \& D$, and if the southern countries accelerated their $S \& T$ development. In particular, educational achievement and the rapid reduction of unacceptable, early drop-out rates in many European countries will be key policy objectives to broaden the qualification pool for $S \& T$ professions" (Gago et al. 2004, p. 6).

Changes in education investment are illustrated in Table 3, which shows the European (EU19) expenditure on educational institutions compared with the OECD average in the years 1995, 2000 and 2006.

Table 3: $\quad$ Change in expenditure on educational institutions for all services per student relative to different factors, by level of education $(1995,2000,2006)$

Index of change between 1995, 2000 and 2006 (GDP deflator 2000=100, constant prices)

\begin{tabular}{|c|c|c|c|c|c|c|c|c|c|c|c|c|}
\hline & \multicolumn{6}{|c|}{$\begin{array}{l}\text { Primary, secondary and post- } \\
\text { secondary } \\
\text { non-tertiary education }\end{array}$} & \multicolumn{6}{|c|}{ Tertiary education } \\
\hline & \multicolumn{2}{|c|}{$\begin{array}{l}\text { Change in } \\
\text { expenditure } \\
(2000=100)\end{array}$} & \multicolumn{2}{|c|}{$\begin{array}{l}\text { Change in } \\
\text { the number } \\
\text { of } \\
\text { students } \\
(2000=100)\end{array}$} & \multicolumn{2}{|c|}{$\begin{array}{l}\text { Change in } \\
\text { expenditure } \\
\text { per student } \\
(2000=100)\end{array}$} & \multicolumn{2}{|c|}{$\begin{array}{l}\text { Change in } \\
\text { expenditure } \\
(2000=100)\end{array}$} & \multicolumn{2}{|c|}{$\begin{array}{l}\text { Change in } \\
\text { the number } \\
\text { of } \\
\text { students } \\
(2000=100)\end{array}$} & \multicolumn{2}{|c|}{$\begin{array}{l}\text { Change in } \\
\text { expenditure } \\
\text { per student } \\
(2000=100)\end{array}$} \\
\hline & 1995 & 2006 & 1995 & 2006 & 1995 & 2006 & 1995 & 2006 & 1995 & 2006 & 1995 & 2006 \\
\hline $\begin{array}{l}\text { OECD } \\
\text { average }\end{array}$ & 88 & 121 & 100 & 98 & 89 & 124 & 83 & 130 & 84 & 118 & 99 & 111 \\
\hline $\begin{array}{l}\text { EU19 } \\
\text { average }\end{array}$ & 89 & 121 & 101 & 97 & 87 & 126 & 82 & 131 & 83 & 117 & 101 & 113 \\
\hline
\end{tabular}

Source:

OECD 2009

On average in OECD countries, expenditure for all levels of education combined increased relatively more than GDP between 1995 and 2006. Table 3 shows that the level is much higher in 2006 compared to 2000. More people are completing upper secondary and tertiary education than ever before, and in many countries this has been accompanied by massive financial investment. In the US, for example, the investment in educational technology increased by over 3,000\%, from \$23 million in 1994 to \$769 million in 2000, including training more than 600,000 new teachers to use technology effectively in the classroom. Such investment clearly shows how strongly the US Administration was determined to support the development of the "information society". Since 1992, the Clinton-Gore Administration has tripled funding for Community Technology Centers, which provide access to computers and the Internet to low-income urban and rural neighbourhoods. It has also challenged the private sector to develop new business models 
for low-cost computers and Internet access to make universal access at home affordable for all. The Technology Literacy Challenge Fund4 has provided \$1 billion in federal resources to help schools work with businesses and community organisations to put modern computers, high-quality educational software, and affordable connections to the Internet in every classroom. The Taxpayer Relief Act of 1997 created a temporary tax deduction for donations of computers to elementary and secondary schools. Some of these policy measures were later adopted by several European governments in their own national policies for the information society.

But just two years after the adoption of the so-called "Lisbon strategy", an assessment document concluded:

"The available reports and indicators all point to the same conclusion, which is that if reform proceeds at the current rate, the Union will be unable to attain its objectives in education and training" and that "the future Member States must make up their delays in developing a knowledge-based economy and society" (European Commission 2003, p. 6).

This means that a few years after the implementation of the Lisbon strategy it was already clear that the basic features for the development of a knowledge-based economy were missing. The task to increase (almost dramatically) the investment on R\&D proved to be too difficult. At the same time, the dependence on the US geo-strategic and economic policies still seemed to be very strong. Most of the European states and the EC as a whole are still following the US as a reference model for a policy towards the development of knowledge society.

Nevertheless, some of the plans have been partially implemented. However, the aims in the field of education and training are still to be integrated in the national policies5. One of the priorities of the EC still is to increase educational attainment, in particular to tackle the problem of early school leavers by reducing the dropout rate to $10 \%$ from the currently $15 \%$. It is intended to increase the share of the population aged 30-34 having completed tertiary education from 31\% to at least 40\% in 2020 (European Commission 2010a). For institutions related to education and knowledge development, the increase in educational levels is a prerequisite for improving their economic (and societal) results. This assumption is based on a wide variety of studies (e.g. Tapscott 1996; Webster 1997; Castells 2002), which demonstrate the influence of average education levels on the economic performance.

Vocational training and education systems have a vital role to play in providing people with competences and qualifications which respond to labour market requirements. In this respect, Europe is in a much more precarious situation then the US or Japan. This is one of the reasons why this issue should be given high priority in the development of a

4 http://clinton5.nara.gov/WH/Accomplishments/eightyears-03.html.

5 One important step was the Bologna process for higher education, which however does not cover all levels of education and training. 
"knowledge society". The above mentioned 2004 report on human resources touches this sensitive point:

"[...] the level of public funding per researcher in Europe is clearly well below that in the US. It is not surprising, therefore, that the number of European researchers, namely in the public sector, does not translate into the same level of working conditions and, consequently, of results. The conditions and prospects for employment by the public sector (by universities, public research centres or other publicly funded research institutions) should be recognised as critical for the EU strategy. New human resources for $S \& T$ will not be attracted at the required level unless governments translate their own political goals urgently into new research jobs and better career perspectives. In periods of economic slowdown, this conclusion is even stronger" (Gago et al. 2004, p. 6).

The US economy was building on the emergence of the so-called "new" knowledge economy and its leadership in information and communication technologies (ICTs) since the Clinton presidency and had begun to outperform all but the very best of the individual European economies.

"Prior to 1993 [and in some European countries even today; the author], the debate on fiscal policy often revolved around a false choice between public investment and deficit reduction. In 1993, the Clinton-Gore plan for deficit reduction showed that deficit and debt reductions could be accomplished in a progressive way by slashing the deficit in half and making important investments [...] in education, health care, and science and technology research. The plan included more than $\$ 500$ billion in deficit reduction [while at the same time $R \& D$ investment increased; the author]. [...]

The Clinton Administration completed a series of trade agreements on technology, including the World Trade Organisation's (WTO) commitment to duty-free cyberspace, keeping the Internet free of trade barriers, in 1998; the global WTO agreements on Financial Services and Basic Telecommunications in 1997; the global WTO agreement on Information Technology in 1996; and a series of bilateral agreements on intellectual property, high-tech products, services and other sectors. [...] The Telecommunications Act contained the E-Rate initiative, which provided low-cost Internet connections for schools, libraries, rural health clinics and hospitals [this measure was innovative at the world level, and replied later also in European countries; the author]. More than 80 percent of America's public schools have benefited from this E-rate, which has helped connect 30 million children and up to 47,000 schools and libraries to the Internet. The percentage of public schools connected to the Internet has increased from 35 
percent in 1994 to 95 percent in 1999. The percentage of classrooms connected to the Internet has increased from 3 percent in 1994 to 63 percent in 1999.6

The report on "Knowledge for Growth" (European Commission - DG Research 2009 b) points out that an R\&D deficit persists in Europe in relation to the US and Japan. This is a symptom of the difficulties in developing new activities and increasing the companies' productivity. One could add that it is a symptom of the inabilities of member states' governments and the EC leadership to support industrial R\&D and the relationship between universities, research institutions, and industry. However, the more traditional sectors (automotive, chemistry, and aerospace) are less affected by such deficit than the IT sector, as they have already supported $R \& D$ activities in the past.7 The IT sector needs major investment on qualification of their workforce and capacity to innovative research and integration in global competition.

"Raising the stock of highly skilled workers in the EU labour force will consequently be a priority in order to support $R \& D$ activity. The share of highly skilled workers in the labour force in Europe is low compared to countries at the leading edge of technology" (Europa NU 2008, p. 22).

An important event was the Lisbon European Council held in March 2000, where all government leaders of the EU member states acknowledged that

"[...] the European Union is confronted with a quantum shift resulting from globalisation and the challenges of a new knowledge-driven economy" (European Parliament 2000)

and set the Union a major strategic goal for 2010

"[...] to become the most competitive and dynamic knowledge-based economy in the world, capable of sustainable economic growth with more and better jobs and greater social cohesion" (ibid., p. 2).

The Council stressed that this would require not only a "radical transformation of the European economy", but also a "challenging programme for the modernisation of social welfare and education systems" (ibid., p. 1). Never before had the European Council acknowledged to this extent the role played by education and training systems in the economic and social strategy and the future of the Union.

Actions by any one Member State, ran the argument of the European Council, would be all the more effective if all other Member States acted in concert.

6 References to the presentation of the White House accomplishments of the Clinton-Gore Administration (cf. http://clinton5.nara.gov/WH/Accomplishments/eightyears-03.html).

7 Further examples are sectors like electronics (excluding IT), metal engineering, and logistics. 
"The more the EU could develop its knowledge and market opening initiatives in tandem, the stronger and more competitive each Member State's economy would be. The Lisbon strategy, as it has come to be known, was a comprehensive, interdependent and self-reinforcing series of reforms" (European Commission 2004, p. 8).

While there were concrete targets, the strategic aims remained unclear. However, without a concrete framework, the implementation of the agreed targets (3\% of GDP, and others) could not be realised.

On the other hand, the Lisbon Strategy helped to build a broad consensus on necessary reforms with regard to information society development (common telecommunications policies, broadband, education and lifelong learning), energy and environment policies, and EU enlargement options. It also reached consensus on the general direction of the EU economic and employment policies. The broad economic policy and employment guidelines adopted in 2000 laid the foundations for the national reform programmes (Presidency of the European Union 2000b). They outlined the key macro-economic, micro-economic and labour market reform priorities for the EU as a whole. However, the guidelines were too ambitious and not sufficiently coordinated, which limited their impact on national policy-making. This became even more evident with the changing international economic and political contexts as of 2001.

There are, however, great differences among Member States regarding the means to achieve particular goals, ranging from more market- and flexibility-oriented measures in the UK National Action Plan to more social policy-oriented instruments in Scandinavian countries. Another problem is a lack of controls and procedures if targets are not met or rules are not followed. Despite some success, e.g. regarding the treatment of the disabled, the banning of discrimination, the improvement of the rights of part-time workers, women and the elderly, most of the targets have not yet been reached (cf. Huws 2006, p. $31)$.

\section{Facing the challenge: the Lisbon strategy re- launched (2005-2010)}

In the last decade, the European Union has grown from 15 Member States in 2000 to 27 Member States today. Also, the membership of the euro-area has grown from 12 countries in 1999 to 16 countries today. The effort to cope with the enlargement process and the organisation of priority areas has led to an instable institutional framework within the EU. The debate on the Lisbon Treaty has shown these tensions.

"However, the renewal of the strategy in 2005 helped clarify its scope and aims. In particular, the definition of four priority areas (research and innovation, investing in people/modernising labour markets, unlocking business potential, 
particularly of SMEs, and energy/climate change) was an important step forward in providing greater focus" (NESC 2010, p.14).

The Lisbon Strategy was re-launched in 2005, after a mid-term review which led to greater focus on growth, more and better jobs. A new governance structure based on a partnership approach between the Member States and the EU institutions was put into place. The report "Facing the challenge: The Lisbon strategy for growth and employment" from the High Level Group nominated by the European Commission and chaired by Wim Kok says:

"The ink had scarcely dried on the agreement before the worldwide stock market bubble imploded, the epicentre of which was the collapse of the overvalued prices of American dot.com and telecom shares amid evidence of financial and corporate malpractice. Scepticism mounted about the potential of the knowledge economy. The US suffered two years of economic slowdown and recession and the European economy followed suit" (European Commission 2004, p. 9).

This situation did not only affect the US but also strongly hit the European and Japanese economies in the beginning of the new millennium. Due to political reasons (September 11 events, beginning of military action in Afghanistan and Iraq, terrorist attacks, financial instabilities), the coordination of policies was very difficult at the international level. This was also felt at the European level and hampered the efforts to develop policies for the "knowledge society". There was a shift towards the financial markets and the military economy. However, due to the general economic and political conditions the European economic performance was disappointing.

Against this background, the High Level Group recommended that European action should focus on five policy areas, one of them being the knowledge society. This meant increasing Europe's attractiveness for researchers and scientists, making R\&D a top priority, and promoting the use of information and communication technologies (ICTs). As mentioned in the Kok report, the knowledge society

"[...] covers every aspect of the contemporary economy where knowledge is at the heart of value added - from high-tech manufacturing and ICTs through knowledge intensive services to the overtly creative industries such as the media and architecture. Up to $30 \%$ of the working population are estimated in future to be working directly in the production and diffusion of knowledge in the manufacturing, service, financial and creative industries alike” (European Commission 2004, p. 19).

From the outset, the Lisbon reform programme "has sought to marry economic dynamism to create higher growth and employment rates with longstanding European concerns to advance social cohesion" (European Commission 2004, p. 8), and has aimed to increase the creation and diffusion of scientific, technological and intellectual capital (ibid.). In more detail, the report states as follows: 
"Success in the knowledge economy was seen as the key to allowing Europe to remain both open and socially cohesive. Europe did not want to compete both internally as an economic union and externally by initiating a race to lower real wage and non-wage costs so that Member States would find their systems of social cohesion, partnership in the workplace and protection of the environment undermined. The more Europe could sustain itself as a high productivity, high value-added, high employment economy, the better able it would be to create the wealth and jobs that would allow it both to sustain its vital commitment to open markets and to social and environmental Europe” (ibid., p. 9).

This is an idealistic aim, a strategic target, and though the actual economic and social conditions in Europe have been quite different, the Lisbon strategy often was and still is viewed optimistically in the official documents of the European Commission.

"The Lisbon strategy is sometimes criticised for being a creature of the heady optimism of the late 1990s about the then trendy knowledge economy, neglecting the importance of the traditional industrial strengths of the European economy" (European Commission 2004, p. 10).

This has not changed up to now - only some concepts and ideas have been replaced. As mentioned before, the focus on the need to support the development of the knowledge economy was a response to the competitive pressure from countries like the US and Japan that have played a leading role in the international arena, both in the field of research and education, with significant impacts on the innovation system. Europe showed evident political determination to follow the receipt. However, the "traditional industrial strengths" lay on the conservative positions of very diverse political orientations in the different member states. This was perhaps the main obstacle to increasing Europe's innovation capacity.

As stated in the Kok report, the criticism of the Lisbon strategy as undervaluing industry is justified:

"It is vital that Europe retains a strong industrial and manufacturing base as a crucial component of a balanced approach to economic growth. Indeed industrial growth and productivity since industrialisation have always been underpinned by advances in technologies and sectors, and Lisbon is based on this longstanding truth. Conversely, a vigorous knowledge economy necessarily needs a strong high-tech manufacturing sector making high-tech goods at the frontier of science and technology" (European Commission 2004, p. 10).

This is an interesting viewpoint, as many influential analysts have emphasised the crucial role of the service sectors in improving the innovation system. These analysts have strongly influenced policy decisions on the allocation of resources. During the first decade of the 21th century, we have therefore seen a shift in terms of political and financial support from the manufacturing industry to the service sector (banking, insurance, telecommunication, transport services, tourism). In the last decades of the 20th century, governments had focused on the creation of infrastructures for economic 
development, mainly supporting large companies and multinationals of the industrial sector (chemical, metal, transport equipment, electronics, construction, etc.). These sectors were the main supporters of labour market qualification but were also the basis for labour movements and the development of the main negotiation principles of social partners. In a certain way, they also provided the framework for the development of democracy and the involvement of workers organisations in the definition of economic and social modernisation of industrial nations. With the above mentioned shift, the deregulation of economic processes together with the development of new technologies and the dissemination of ICT in all productive sectors led to the emergence of new social actors and the decline of the need for national, supra-national or sectoral agreements and labour arrangements.

The challenges of developing the "digital economy" posed new problems for European economic policies: Should the large industrial groups receive greater support to face the need for restructuring? Or instead: Should more support be given to the new companies, service providers and service producers, and also to the networks from which such SMEs emerge and which integrate new qualified employees. There is a clear need for change, says the Kok report:

"In a global economy, Europe has no option but radically to improve its knowledge economy and underlying economic performance if it is to respond to the challenges of Asia and the US" (European Commission 2004, p. 12).

While being widely accepted by European politicians, this goal is difficult to achieve. There is still disagreement about the question whether the "knowledge economy" is to be considered as a modern service economy where the traditional industrial sectors are no longer able to meet the economic performance targets. It seems difficult to accept that all sectors are facing important structural changes. Without strong support for employment and continuous learning, as well as for research activities in all productive sectors, the European member states and companies will not be able to face the competitive challenges. Thus, new solutions are needed for the next decades.

\section{The Europe 2020 strategy for "smart growth"}

An underlying aim of the Europe 2020 strategy is to achieve a "smart growth". And what is considered as "smart growth"? According to the European Commission, this concept means:

"[...] strengthening knowledge and innovation as drivers of our future growth. This requires improving the quality of our education, strengthening our research performance, promoting innovation and knowledge transfer throughout the Union, making full use of information and communication technologies and ensuring that innovative ideas can be turned into new products and services that 
create growth, quality jobs and help address European and global societal challenges" (European Commission 2010a, p. 10).

The "smart growth" target is to foster knowledge, innovation, education and digital society.

With the new Europe 2020 strategy, the European Commission has introduced seven flagship initiatives to catalyse progress under three priority themes - smart growth, sustainable growth, and inclusive growth -, following the principles of the Lisbon strategy of 2000. These initiatives include (cf. European Commission 2010a, 2010b, and Rodrigues, 2010):

- "Innovation Union" to improve framework conditions and access to finance for research and innovation so as to ensure that innovative ideas can be turned into products and services that create growth and jobs.

- "Youth on the move" to enhance the performance of education systems and to facilitate the entry of young people to the labour market.

- "A digital agenda for Europe" to speed up the roll-out of high-speed internet and reap the benefits of a digital single market for households and firms.

- "Resource efficient Europe" to help decouple economic growth from the use of resources, support the shift towards a low carbon economy, increase the use of renewable energy sources, modernise our transport sector and promote energy efficiency.

- "An industrial policy for the globalisation era" to improve the business environment, notably for SMEs, and to support the development of a strong and sustainable industrial base able to compete globally.

- "An agenda for new skills and jobs" to modernise labour markets and empower people by developing their skills throughout the lifecycle with a view to increase labour participation and better match labour supply and demand, including through labour mobility.

- "European platform against poverty" to ensure social and territorial cohesion such that the benefits of growth and jobs are widely shared and people experiencing poverty and social exclusion are enabled to live in dignity and take an active part in society.

The flagship initiative "Innovation Union" is intended to improve framework conditions for business to innovate (i.e. create the single EU Patent and a specialised Patent Court, modernise the framework of copyright and trademarks, improve access of SMEs to Intellectual Property Protection, speed up setting of interoperable standards; improve 
access to capital and make full use of demand side policies, e.g. through public procurement and smart regulation). A further aim is to promote knowledge partnerships and strengthen links between education, business, research and innovation, e.g. through the European Institute of Innovation and Technology (EIT), and to promote entrepreneurship by supporting young innovative companies.

Another so-called flagship initiative, the "Digital Agenda for Europe", is "to promote internet access and take-up by all European citizens, especially through actions in support of digital literacy and accessibility" and to "speed up the roll-out of high-speed internet and reap the benefits of a digital single market for households and firms". Other flagship initiatives are related to energy, industrial policies and competitiveness. A strong focus is now placed on financial instruments to support economic stimulus with expected sideeffects like diminishing poverty, increasing restructuring and adaptability (European Commission 2010a).

The EU flagship initiative "Youth on the Move" aims at enhancing the performance of education systems and reinforcing the international attractiveness of Europe's higher education.

The "Agenda for New Skills and Jobs" is a well-known flagship initiative to boost "Inclusive Growth". It aims to

"[...] create conditions for modernising labour markets with a view to raising employment levels and ensuring the sustainability of our social models. This means empowering people through the acquisition of new skills to enable our current and future workforce to adapt to new conditions and potential career shifts, reduce unemployment and raise labour productivity" (European Commission 2010a, p. 16-17).

The Europe 2020 strategy will be organised around a thematic approach and more focused country surveillance. The country reporting is intended to
"[...] contribute to the achievement of Europe 2020 goals by helping Member
States define and implement exit strategies, to restore macroeconomic stability, identify national bottlenecks and return their economies to sustainable growth and public finances. [...] To achieve this, the Europe 2020 and Stability and Growth Pact (SGP) reporting and evaluation process will be done simultaneously to bring the means and the aims together, while keeping the instruments and procedures separate and maintaining the integrity of the SGP" (European Commission 2010a, p. 25).

The "Europe 2020 Integrated Guidelines" set out the framework for the Europe 2020 strategy and reforms at Member State level. In this process, the Member States will draw up National Reform Programmes setting out in detail the actions they will take under the new strategy.

The Europe 2020 strategy is underpinned by a smaller set of guidelines, replacing the previous set of 24 of the Lisbon strategy. These are supposed to address employment and 
broad economic policy issues in a more coherent manner. Ten guidelines were approved, but only few of them are related to the development of a knowledge-based society. They are the following:

\begin{tabular}{|ll|}
\hline Guideline 1: & Ensuring the quality and the sustainability of public finances \\
Guideline 2: & Addressing macroeconomic imbalances \\
Guideline 3: & Reducing imbalances in the euro area \\
Guideline 4: & $\begin{array}{l}\text { Optimising support for R\&D and innovation, strengthening the knowl- } \\
\text { edge triangle and unleashing the potential of the digital economy }\end{array}$ \\
Guideline 5: & $\begin{array}{l}\text { Improving resource efficiency and reducing greenhouse gases } \\
\text { emissions }\end{array}$ \\
Guideline 6: & $\begin{array}{l}\text { Improving the business and consumer environment and modernising } \\
\text { the industrial base }\end{array}$ \\
Guideline 7: & $\begin{array}{l}\text { Increasing labour market participation and reducing structural unem- } \\
\text { ployment }\end{array}$ \\
Guideline 8: & $\begin{array}{l}\text { Developing a skilled workforce responding to labour market needs, } \\
\text { promoting job quality and lifelong learning }\end{array}$ \\
Guideline 9: & $\begin{array}{l}\text { Improving the performance of education and training systems at all } \\
\text { levels and increasing participation in tertiary education }\end{array}$ \\
Guideline 10: & $\begin{array}{l}\text { Promoting social inclusion and combating poverty } \\
\text { and }\end{array}$
\end{tabular}

Guidelines 4, 8 and 9 can be pointed out as being more closely related to the aims of economic growth and the transition towards a knowledge society, i.e. research and innovation, learning and skills, and advanced education. It has to be noted that "knowledge" is understood here as relating the innovation dimension (R\&D, product and process modernisation, patents) to the dimension of knowledge and skills in economic life (training, education, qualification). Politically, there are other dimensions like social inclusion, economic balance, environmental aspects and industrial development which are not directly related to the characteristics of the knowledge society. A more detailed look at these guidelines can enlighten this relation between innovation and education as main elements of knowledge:

Guideline 4 aims at optimising support for R\&D and innovation, strengthening the knowledge triangle and unleashing the potential of the digital economy:

"Member States should review national (and regional) $R \& D$ and innovation systems, ensuring adequate and effective public investment, and orienting them 
towards higher growth while addressing major societal challenges (for example energy, resource efficiency, climate change, social cohesion, ageing, health, and security). The reforms should foster excellence and smart specialisation, promote scientific integrity, reinforce cooperation between universities, research institutes, public, private and third sector players, both domestically and internationally and ensure the development of infrastructures and networks that enable knowledge diffusion. The governance of research institutions should be improved to make national research systems more effective. To this end university-based research should be modernised, world class infrastructures developed, attractive careers and mobility of researchers promoted. National funding and procurement schemes should be adapted and simplified to facilitate cross-border cooperation, knowledge transfer and merit-based competition" (European Commission 2010b, p. 13).

"In line with guidelines 8 and 9, Member States should equip people with a broad range of skills needed for innovation in all its forms, and should ensure a sufficient supply of science, mathematics and engineering graduates. School curricula should strive to support creativity, innovation, and entrepreneurship" (European Commission 2010b, p. 9).

The focus is on the promotion of the roll-out and take-up of high-speed internet as an essential means for accessing knowledge and participating in its creation.

The aim of Guideline 8 is to "develop a skilled workforce responding to labour market needs, promoting job quality and lifelong learning":

“Member States should promote productivity and employability through an adequate supply of knowledge and skills to match current and future demand in the labour market. Quality initial education and attractive vocational training must be complemented with effective incentives for lifelong learning [...], thus ensuring every adult the chance to retrain or to move one step up in their qualification [...], as well as by opportunities for second-chance learning and by targeted migration and integration policies. Member States should develop systems for recognising acquired competencies [...]. In particular, efforts should focus on supporting those with low and obsolete skills, increasing the employability of older workers, enhancing training, skills and experience of highly skilled workers, including researchers" (http://eur-lex.europa.eu).

Guideline 9 on "Improving the performance of education and training systems at all levels and increasing participation in tertiary education" is designed to ensure access to quality education and training for all and to improve educational outcomes.

"Member States should invest efficiently in education and training systems notably to raise the skill level of the EU's workforce, allowing it to meet the rapidly changing needs of modern labour markets [...] action should cover all sectors (from early childhood education and schools through to higher education, vocational education and training, as well as adult learning) taking into account 
also learning in informal and non-formal contexts. Reforms should aim to ensure the acquisition of the key competencies that every individual needs for success in a knowledge-based economy, notably in terms of employability in line with the priorities mentioned in guideline 4 [further learning and ICT skills; the author]. [...]. Steps should also be taken to ensure that learning mobility for young people and teachers becomes the norm. Member States should improve the openness and relevance of education and training systems, particularly by implementing national qualification frameworks enabling flexible learning pathways, and by developing partnerships between the worlds of education/training and work. The teaching profession should be made more attractive [...]. Higher education should become more open to non-traditional learners and participation in tertiary or equivalent education should be increased. With a view to reducing the number of young people not in employment, education, or training, Member States should take all necessary steps to prevent early school leaving" (http:/leurlex.europa.eu).

The aim is to reduce the dropout rate to $10 \%$, whilst increasing the share of the population aged 30-34 having completed tertiary or equivalent education to at least $40 \%$ in 2020.

Since the beginning of the 1990s, the term "knowledge-based society" has become increasingly important in the scientific and political debate. Though there is broad consensus on describing post-industrialised societies as "knowledge societies", the descriptions focus on a variety of aspects. From the technology perspective, the term "knowledge society" refers to the concept of the information society with a strong bias on information and communication systems. Here, the introduction of information technologies and information systems has led to profound changes in different societal spheres such as the manufacturing and service sector.

A deep transformation of the function of "knowledge" in modern societies is also indicated by changes within and between organisations in the public and private sectors, as well as in the service and manufacturing sectors. Current commodification processes are double-edged. All change processes are therefore characterised by strong dynamics. Any innovation requires a new cohort of "knowledge workers" who bring about the routinisation of the work of others in the same sector, or even in the same service or company. "Upskilling" therefore goes hand in hand with "downskilling" and new forms of specialisation come along with increasingly generic activities. Thus, the development towards knowledge-based economies has different impacts on different social groups. Those were some of the main conclusion from the international research project WORKS that also have been mentioned in this book (cf. Huws et al. 2006; Ramioul 2008; Ramioul, De Vroom 2009).

It can be concluded that the complex dynamics of recent changes in modern economies are difficult to translate into national policies. This applies even more to supra-national policies, i.e. at the European Union level or at the economic and political coordination levels. 


\section{Conclusions}

Based on the current theoretical debate around the "knowledge society" as well as on empirical results of different research projects, the aim of the approach followed in this paper is to analyse and discuss comprehensively the function of "knowledge" in different societal spheres in numerous European countries. Hereby, this perspective aims to connect the macro with the micro level. And this can be done in particular at the work processes levels. The function of knowledge at the macro level is connected with the analysis of labour market policies, the education and training strategies, or the relation between research and economic productivity. At the micro level it can be understood in the impact results of the concrete policies taken into consideration.

Coming from the discussion of qualitative changes of the knowledge structure in modern societies, different changes of the knowledge structure within occupational groups of some economic sectors will be provided. Changes of qualification and skills are embedded into institutional systems of vocational training and of production organisations, as well as into the expectation of long life learning in order to gain flexibility in the production processes.

These expectations have been highly strengthened by the European Commission in the last decade. The contributions (Huws 2006; Ramioul 2008; Rodrigues 2010) dealing with qualification and skills are, however, discussing critically whether these aims are still missing in these European policies. The aims should also correspond to real demands on the labour markets. Probably, the dominant economic structures are still not prepared for a deep restructuring process that would also improve the quality of working standards.

As mentioned in this paper, the Lisbon Strategy was criticised by many politicians and opinion-makers in the first years of this century. The argument was that the European structures were not prepared for such a quick change. At the same time, critics feared that the focus of investment would shift away from the traditional support of industrial sectors (manufacturing, agriculture and fisheries, construction) to the "new economy" sectors. The shadows of recent recessions have strongly questioned the options made by the European Council.

The need to improve competitiveness in a knowledge-based society is still far too generic and unclear, especially after the financial crisis of 2008, which pushed almost all European economies into a critical economic uncertainty with subsequent social conflicts and degradation.

The "Europe 2020" strategy points out the need for redefining collective strategies in terms of European development. The new concept of "smart growth" introduced by this strategy links knowledge-related features of economic structures with economic performance with the aim to increase competitiveness. However, the recent problems arising from the financial crisis of 2008 and 2009 clearly show how difficult it will be to 
interconnect the two key elements of this concept: knowledge and growth. Common strategies at the European level are strongly needed, and it is no longer possible to respond to these challenges merely at a national level.

But up to now, no clear path has been defined. It is still questionable whether there is a real "European strategy" towards social and economic cohesion, improvement of the quality of life, and improvement of working life standards - in other words, towards a "knowledge society" - which is funded by a European welfare system and is able to compete both at the global and at the regional level. Improving the quality of working life implies sustainable improvement of the quality of the products manufactured. It is not yet clear whether the Europe 2020 strategy will contribute to higher levels of innovation, demanding higher education and qualification levels of the labour force. Up to the present, the development path set out in the strategy has been followed neither at the national, nor even at the European level. Whether it is progress for the European economies, or again an illusion, remains to be seen.

\section{References}

- Berting, J.; Mills, S.C.; Wintersberger, H. (eds.) (1980): The Socio-Economic Impact of Microelectronics. Oxford.

- Braun, D. (2008): Organising the political coordination of knowledge and innovation policies. Science and Public Policy 35, pp. 227-239

- Bureau of Labor Statistics (2009): International comparisons of GDP per capita and per employed person: 17 countries, 1960-2008, Division of International Labor Comparisons, Washington

- Castells, M. (2002): A Sociedade em Rede. Lisbon (In English: The Network Society. Blackwell 1996)

- Cornfield, D.B.; Campbell, K.E.; McCammon, H.J. (2001): Working in Restructured Workplaces - Challenges and New Directions for the Sociology of Work, Thousand Oaks

- CREST - Scientific and Technical Research Committee (2008): CREST Guidelines: Coordinating the research Framework Programme and the Structural Funds to support Research and Development. EUR 23458, Brussels. http://ec.europa.eu/invest-inresearch/pdf/down load_en/2008_1251_deliverable_web.pdf (last accessed 07.03.2011)

- European Commission (1985): Completing the Internal Market: White Paper from the Commission to the European Council (Milan, 28-29 June 1985). COM(85) 310

- European Commission (1994), Growth, competitiveness, employment - The challenges and ways forward into the 21st Century, Luxembourg: Office for Official Publications of the European Communities 
- European Commission (2003): Draft joint interim report on the implementation of the detailed work programme on the follow-up of the objectives of education and training systems in Europe. SEC(2003) 1250

- European Commission (2004): Facing the challenge: The Lisbon strategy for growth and employment. Report from the High Level Group chaired by Wim Kok, Luxembourg

- European Commission (2005): Growth and jobs - A new start for the Lisbon strategy. Luxembourg

- Europa NU (2008): Restructuring in Europe 2008 - A review of EU action to anticipate and manage employment change. http://www.europa-nu.nl/id/vi7jgtahe7zw/commission_ staff_working_document (last accessed 29.01.2011)

- European Commission - DG Research (2009a): The Open Method of Coordination in Research Policy: Assessment and Recommendations. Brussels. http://ec.europa.eu/in vest-in-research/pdf/download_en/eur_23874 texte web.pdf (last accessed 07.03.2011)

- European Commission - DG Research (2009b): Knowledge for Growth-Prospects for science, technology and innovation. Brussels. http://ec.europa.eu/invest-in-research/ pdf/download_en/selected_papers_en.pdf (last accessed 07.03.2011)

- European Commission (2010a): EUROPE 2020 - A strategy for smart, sustainable and inclusive growth. $\operatorname{COM}(2010) 2020$

- European Commission (2010b): Europe 2020 Integrated guidelines for the economic and employment policies of the Member States. Recommendation SEC(2010) 488 final

- European Commission (2010c): Lisbon Strategy evaluation document-Commission Staff Working Document, SEC(2010) 114 final

- European Council (2002): Presidency Conclusions - Barcelona European Council, 15 and 16 March 2002. SN 100/1/02 REV 1. http://www.consilium.europa.eu/uedocs/cms data/docs/pressdata/en/ec/71025.pdf (last accessed 07.03.2011)

- European Parliament (2000): Lisbon European Council, 23 and 24 March 2000 Presidency Conclusions. http://www.europarl.europa.eu/summits/lis1_en.htm (last accessed 29.01.2011)

- European Parliament (2001): Report on the Spring 2001 European Council: The Lisbon process and the path to be followed. A5-0034/2001, 30.01.2001

- Friedrichs, G. (1980): Microelectronics - A New Dimension of Technological Change and Automation. In: Berting, J.; Mills, S.C.; Wintersberger, H. (eds.) (1980): The SocioEconomic Impact of Microelectronics. Oxford, pp. 43-67

- Gago, J.M.; Ziman, J.; Caro, P.; Constantinou, C.; Davies, G.; Parchmann, I.; Rannikmäe, M.; Sjoberg, S. (2004): Increasing Human Resources for Science and Technology in Europe. High Level Group on Human Resources for Science and Technology, EC, Brussels 
- Huws, U. (2006): The transformation of work in a global knowledge economy: towards a conceptual framework. Leuven

- IUS - Innovation Union Scoreboard (2011): Innovation Union Scoreboard 2010: The Innovation Union's Performance Scoreboard for Research and Innovation, Pro Inno Europe, UNU/MERIT. http://ec.europa.eu/enterprise/policies/innovation/files/ius-

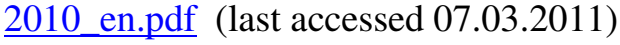

- NESC - National Economic and Social Council (2010): Perspectives on the Evolution of European Social Policy. Background paper 4, Dublin, p. 14

- OECD - Organisation for Economic Co-operation and Development (2009): Education at a Glance 2009 - OECD Indicators, OECD, Paris

- OECD - Organisation for Economic Co-operation and Development (2010a): Main Science and Technology Indicators. Volume 2009/2, Paris

- OECD - Organisation for Economic Co-operation and Development (2010b): The OECD Innovation Strategy - Getting a Head Start on Tomorrow. Paris

- Presidency of the European Union (2000a): Note on the ongoing experience of the open method of co-ordination. 9088/00, 14.06.2000

- Presidency of the European Union (2000b), Document from the Presidency Employment, Economic Reforms and Social Cohesion - Towards a Europe based on innovation and knowledge. Council of the European Union 5256/00, 12.01.2000

- Ramioul, M. (2008): Work organisation and restructuring in the knowledge society. In: Enterprise and Work Innovation Studies 4, pp. 9-19

- Ramioul, M.; De Vroom, B. (2009): Global value chain restructuring and the use of knowledge and skills. Leuven

- Rodrigues, M.J. (2005): The Debate over Europe and the Lisbon Strategy for Growth and Jobs. Background Paper, Lisbon

- Rodrigues, M.J. (2010): On the EU2020, from Lisbon. In: The Lisbon Agenda Group: On The EU2020 Strategy: Contributions after the Lisbon Agenda experience. http://www.maria joaorodrigues.eu/files/EU202020_Contributions_100112_Final.pdf (last accessed 23.03.2011)

- Tapscott, D. (1996): The Digital Economy: Promise and peril in the age of networked intelligence. New York

- UN - United Nations (2000): The World Economy in 2000. United Nations publication, Sales No. E.00.II.C.1. http://www.un.org/esa//analysis/wess/ wess00c1.pdf (last accessed 18.01.2011)

- Webster, F. (1997): Theories of the Information Society. London 
